\title{
Occurrence of the globeflower Trollius europaeus L. in "Ląki w Komborni" Natura 2000 site (Podkarpackie Province, SE Poland)
}

\author{
Maria Ziaja*, Tomasz Wójcik \\ Department of Natural Sciences, Faculty of Physical Education, University of Rzeszów, \\ Cicha 2A, 35-326 Rzeszów, Poland, "e-mail:mziaja@ur.edu.pl
}

\begin{abstract}
The paper presents characteristics of a meadow community with Trollius europaeus, threats posed to the community, and proposals for active protection thereof. The study was carried out in the "Ląki w Komborni" Natura 2000 site (PLH 180042) in the Podkarpacie Province (SE Poland). In 2015, 20 relevés were taken with the Braun-Blanquet method and they are presented in a synthetic table. Additionally, the number of clumps, the number of flowering shoots per clump, and the height of flowering shoots were determined. The community with Trollius europaeus was classified into the alliance Molinion caeruleae with Selinum carvifolia, Galium boreale, Succisa pratensis, Betonica officinalis, Gladiolus imbricatus, and Carex tomentosa as characteristic species. Scrub species, in particular Filipendula ulmaria, had a substantial share, which indicated long-term abandonment of land use. The community also comprised rush species (Carex gracilis, Phragmites australis) and a numerous group of species from the order Arrhenatheretalia (e.g. Geranium pratense, Alchemilla monticola, Galium mollugo, Arrhenatherum elatius) and the class Molinio-Arrhenatheretea (e.g. Lathyrus pratensis, Alopecurus pratensis, Ranunculus acris, Poa pratensis). Abandonment of extensive land use leading to progressive secondary succession is the major threat to phytocoenoses with Trollius europaeus. To preserve meadows with Trollius europaeus, active protection involving mowing and removal of biomass is recommended.
\end{abstract}

Key words: Molinion caeruleae, plant communities, protected species, active protection, threats.

\section{Introduction}

The globeflower (Trollius europaeus L.) species has a Euro-Siberian range covering nearly the entire Europe and western Siberia (Piękoś-Mirkowa \& Mirek 2003; Zając \& Zając 2009). In Poland, its occurrence is fragmented, with the greatest density in Lubelszczyzna region, whereas in Podkarpacie the species is very rare (Zając \& Zając 2001). In our country, Trollius europaeus is a strictly protected species (Regulation of the Minister of the Environment... 2014). Given the progressive loss of its habitats, Trollius europaeus has been included in many regional lists of endangered species. In Opolszczyzna, it is regarded as a critically endangered (CR) species (Nowak et al. 2008). In Lower Silesia (Kącki et al. 2003), Śląskie Province
(Bernacki et al. 2000; Parusel \& Urbisz 2012), Western Pomerania (Żukowski \& Jackowiak 1995), Wielkopolska (Jackowiak et al. 2007), central Poland (Jakubowska-Gabara \& Kucharski 1999), and in the area of Południowopodlaska Lowland (Głowacki et al. 2003), Trollius europaeus represents the group of vulnerable (VU) taxa. With the low-risk category (LR), it can be found on the list of threatened-with-extinction and endangered species from the Lublin Upland, Roztocze, Polesie Lubelskie region, and Western Volhynia (Kucharczyk \& Wójciak 1995). It has also been listed with the VU category in the Red Book of the Łódź Province (Kołodziejek 2012).

Trollius europaeus is a characteristic species for wet meadows from the order Molinietalia caeruleae and the association Polygono bistorte-Trollietum europaei. It also occurs at forest margins and in fringe communities (Ma- 
tuszkiewicz 2008); it is less frequent in rush communities (Kochanowska \& Gamrat 2007). The species grows on moist, eutrophic soils with acidic to alkaline $\mathrm{pH}$. It prefers full light and moderately cold climate conditions (Zarzycki et al. 2002).

Molinion caeruleae meadows are one of the richest meadow communities and a habitat for many rare and protected plant species (Trąba 1997; Kołodziejek \& Michalska-Hejduk 2004; Řezníčková 2007; Suder 2007; Bochnak 2011; Kącki \& Michalska-Hejduk 2010; Kulik 2014). They also represent the most valuable semi-natural communities in Poland and Europe (Kącki \& Załuski 2004; Zelnik 2005; Havlová 2006; Michalska-Hejduk \& Kopeć 2012). Molinion caeruleae phytocoenoses occupy specific moist habitats characterised by temporarily stagnant water in spring and low water levels in summer. They are semi-natural communities associated with human economic activity. They require appropriate agrotechnical treatments that will contribute to conservation of their floristic and phytocoenotic diversity (Załuski 2007).

In the second half of the $20^{\text {th }}$ century, meadows underwent rapid transformation. Disappearance or transformation of meadow communities is usually caused by anthropogenic factors, e.g. abandonment of management, intensive fertilisation, or changes in water relations. This process has been progressing rapidly both in Poland and across Europe (Kotańska 1993; Michalska-Hejduk 2001; Załuski 2007; Řezníčková 2007; Sienkiewicz-Paderewska et al. 2012, Trąba \& Wolański 2012). The reduction of the surface area of Molinion caeruleae meadows has resulted in a decline in biodiversity and loss of localities of a number of rare species (Jakubowska-Gabara \& Kucharski 1999; Bochnak 2011; Michalska-Hejduk \& Kopeć 2012; Trąba \& Wolański 2012; Kulik 2014). Based on the Habitats Directive, variable-moisture Molinion caeruleae meadows have been classified as habitats that should be protected as Natura 2000 areas (Directive 1992; Kącki \& Załuski 2004).

The aim of the study was to determine the species composition and characteristics of a community with Trollius europaeus located in "Łąki w Komborni", a Natura 2000 site, and to indicate threats as well as methods for active protection of the community.

\section{Materials and methods}

The field study was conducted in 2015 in the "Eąki w Komborni" Natura 2000 site (PLH 180042) located in Krościenko Wyżne Commune, Podkarpackie Province, (SE Poland). According to the physical-geographical regionalisation by Kondracki (2011), the study area belongs to the Jasło-Krosno Basin mesoregion, which is a part of the Western Carpathians. In geobotanical terms, the area is a part of the Jasło-Sanok Depression (Oklejewicz 1993,
1996). The study area comprises the largest Trollius europaeus locality in the Jasło-Sanok Depression (Łuczaj \& Oklejewicz 2001), and the main aim of protection of this area is to conserve the variable-moisture Molinion caeruleae meadows (Luczaj 2011).

The investigations were based on 20 relevés taken with the commonly used Braun-Blanquet method. The nomenclature of vascular plants followed that proposed by Mirek et al. (2002) and moss names were adopted from Ochyra et al. (2003). The phytosociological affiliation of species followed the system developed by Matuszkiewicz (2008). Additionally, the number of clumps, the number of flowering shoots per clump, and the height of flowering shoots in Trollius europaeus were determined.

\section{Results}

The localities with Trollius europaeus in the study area are located within stands of disturbed Molinion caeruleae meadows from the alliance Molinion caeruleae. Variable moisture conditions and long-term abandonment of these meadows have contributed to development of a mosaic of diverse habitats. The meadow community in this area is one of the richest phytocoenoses in terms of the floristic composition, since the number of species per relevé ranged from 15 to 50 with an average number of 33 . The total number of species in the community was 87 (Table 1). Six species from the alliance Molinion caeruleae were noted, the most frequent of which were Galium boreale ( $\mathrm{S}=\mathrm{III})$, Selinum carvifolia $(\mathrm{S}=\mathrm{IV})$, and Succisa pratensis $(\mathrm{S}=\mathrm{III})$. Other species, i.e. Carex tomentosa, Gladiolus imbricatus, and Betonica officinalis, were characterised by low stability and insignificant coverage.

A substantial share in the community was noted in the case of scrub species characteristic for the alliance Filipendulion ulmariae. Filipendula ulmaria, which was a dominant or co-dominant species in all the relevés, was particularly abundant $(S=V, D=3000)$. High stability and coverage were also exhibited by Veronica longifolia $(S=V, D=467)$, whereas the share of Lythrum salicaria and Lysimachia vulgaris was inconsiderable.

Cirsium rivulare $(\mathrm{S}=\mathrm{V}, \mathrm{D}=1876)$, a species characteristic for the alliance Calthion, and Geum rivale, i.e. a differential species with stability degree IV, were the permanent elements of the community. There were few representatives of the other species of this alliance (Juncus conglomeratus, Myosotis palustris, Cirsium canum), and they formed small clusters.

Species associated with Molinion caeruleae meadows were also represented by Sanguisorba officinalis $(\mathrm{S}=\mathrm{V})$ and Serratula tinctoria ( $\mathrm{S}=\mathrm{III})$ from the order Molinietalia. The order with stability degree V included Angelica sylvestris and Lychnis flos-cuculi, whereas Deschampsia 


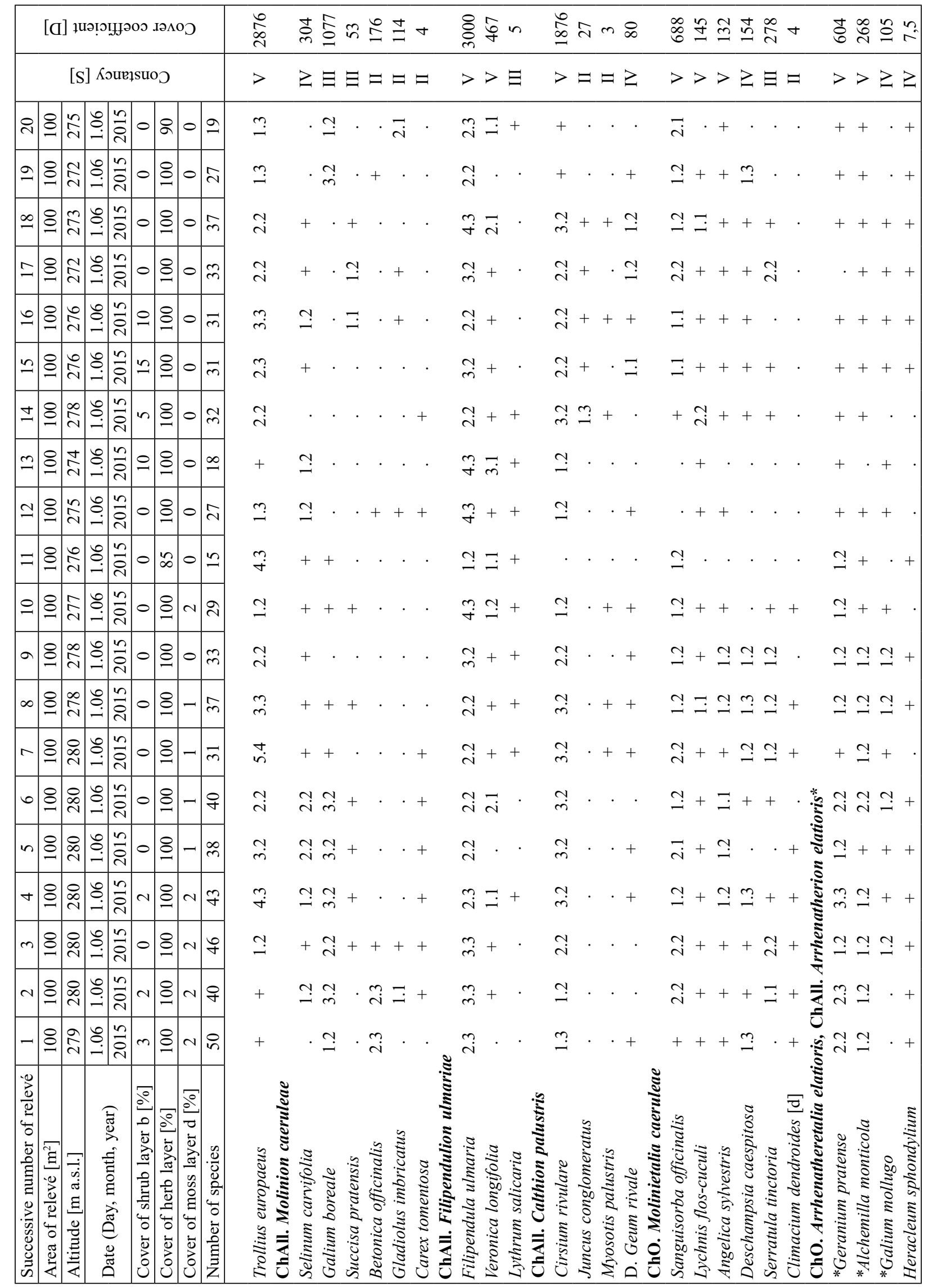




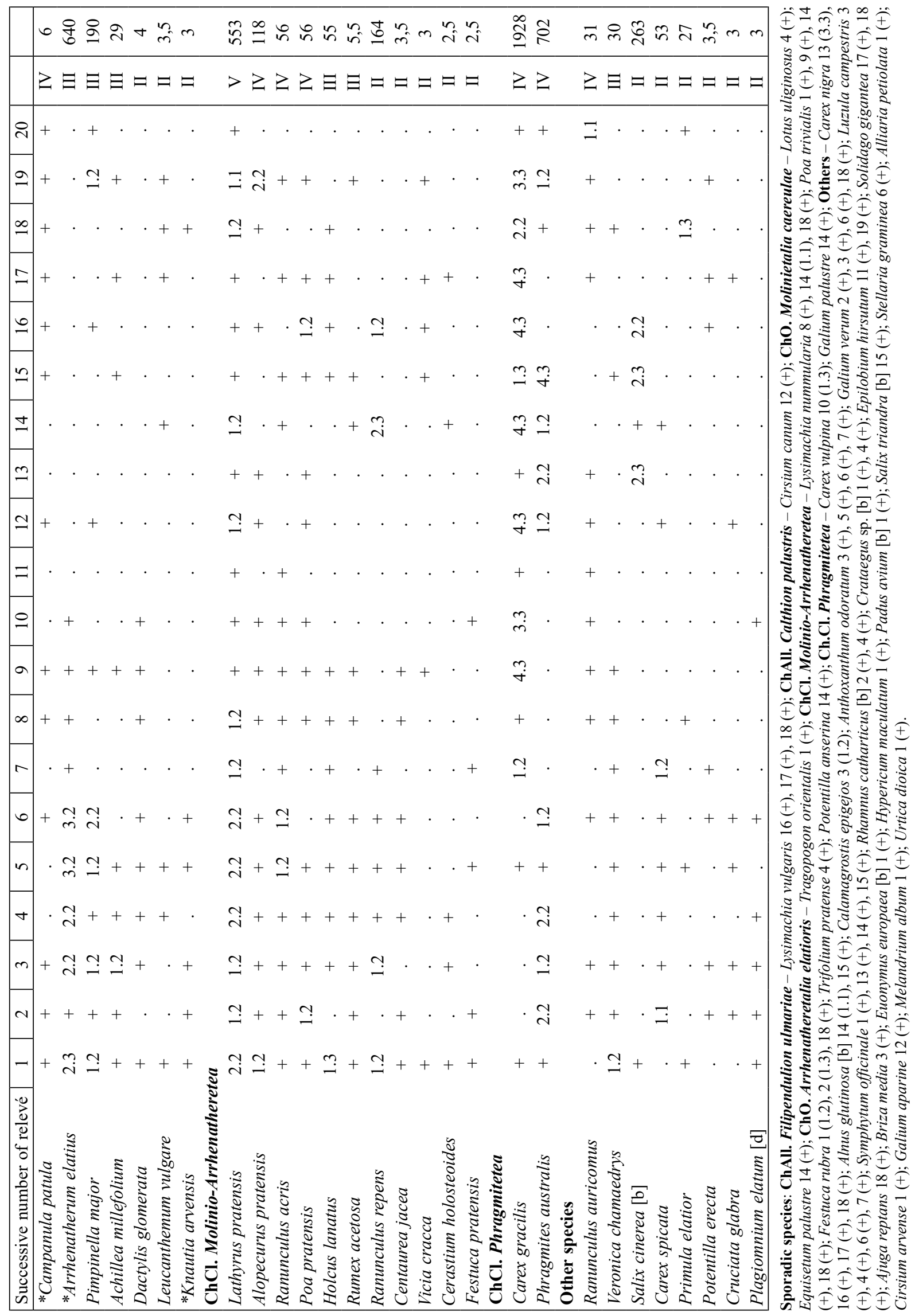


caespitosa was noted less frequently and was characterised by stability degree IV. Furthermore, the moss layer comprised sparse representatives of Climacium dendroides.

A significant share of species characteristic for fresh meadows from the order Arrhenatheretalia elatioris and the alliance Arrhenatherion elatioris was noted. High stability degrees were exhibited by Geranium pratense, Alchemilla monticola, Galium mollugo, Campanula patula, and Heracleum sphondylium.

Species characteristic for the class Molinio-Arrhenatheretea represented a high share in the community. Lathyrus pratensis reached the highest stability degree and cover coefficient, whereas Alopecurus pratensis, Ranunculus acris, and Poa pratensis exhibited stability degree IV and inconsiderable coverage. The occurrence of other diagnostic species was marginal.

The phytocoenoses with Trollius europaeus were characterised by the presence of grass and sedge rush species. High stability and coverage coefficients were noted for Carex gracilis and Phragmites australis, which served a function of a dominant species in some stands.

Accompanying species with high stability but low coverage values were represented by Ranunculus auricomus and Veronica chamaedrys. This group also comprised single specimens of trees and shrubs, i.e. Alnus glutinosa, Rhamnus catharticus, Crataegus sp., Euonymus europaea, Padus avium, and Salix triandra.

Besides Trollius europaeus, two protected species Gladiolus imbricatus and Primula elatior were noted in the community.

In the study area, in total 1010 Trollius europaeus clumps were found in the relevés. The results of measurements of selected individual features of the population are presented in Table 2 .

\section{Discussion and conclusions}

The analysed meadow stands in the "Łąki w Komborni" Natura 2000 site, which was characterised by the presence of Trollius europaeus, were classified as variable-moisture Molinion caeruleae meadows. In the meadow vegetation in Poland, Trollius europaeus most frequently occurs in the association Molinietum caeruleae, where it reaches the highest coverage (Kochanowska 1995; Kochanowska \& Gamrat 2007; Bochnak 2011). In the northern part of the Śląskie Province, Kołodziejek and Michalska-Hejduk (2004) described a community with the globeflower as a typical variant of the sub-association Molinietum caeruleae cirsietosum rivularis due to the permanent presence of the differential species Cirsium rivulare. In turn, in the south-eastern part of the Silesian Upland, Babczyńska-Sendek (2009) reported the association Cirsietum rivularis from the alliance Calthion palustris with the ana-
Table 2. Measurement of individual features of populations of Trollius europaeus L.

\begin{tabular}{|l|c|c|c|}
\hline Population Trollius europaeus L. & Min. & Max. & Mean \\
\hline Number of clumps in relevé & 1 & 250 & 50 \\
\hline Number of flowering shoots per clump & 5 & 14 & 10 \\
\hline Height of flowering shoots [cm] & 55 & 112 & 86.5 \\
\hline
\end{tabular}

lysed species. In Western Pomerania, phytocoenoses with Trollius europaeus were classified into the association Polygono bistortae-Trollietum europaei comprising two sub-associations Polygono-Trollietum caricetosum nigrae and Polygono-Trollietum filipenduletosum (Ćwikliński \& Jasnowski 1997).

The species was also noted in rush communities, where it formed single clumps limited by expansion of Phragmites australis (Kochanowska 1995; Kochanowska \& Gamrat 2007).

Due to the abandonment of the Molinion caeruleae meadows, the community is rapidly colonised by Filipendula ulmaria, i.e. a species with a specific biology of development facilitating encroachment onto unmown meadows within a short time. Kochanowska (1995) described the occurrence of the globeflower in the association Filipendulo-Geranietum from the alliance Filipendulion ulmariae in central Pomerania. In turn, Dembicz et al. (2011) reported stands in central Poland with the globeflower in scrub communities from the alliance Molinion caeruleae comprising abundant Filipendula ulmaria specimens.

Furthermore, literature provides information about the distribution of Trollius europaeus in forest communities from the order Querco-Fagetea and fringe communities from the order Glechometalia (Ciosek et al. 2013). The authors suggest that the occurrence of the globeflower in forest communities supports the hypothesis that these are the primary habitats of the species in Europe. Primeval forests in Europe had a character of woodland pastures with open grasslands, whereas semi-natural meadows remaining after forest clearing are a secondary habitat requiring extensive management.

Investigations of the genus Trollius are also focused on determination of its ecological structure and morphological variability, which are used for assessment of the condition of the population and possibilities of its development (Antkowiak 1999, 2002; Juśkiewicz-Swaczyna et al. 2008; Muncaciu et al. 2010; Kostrakiewicz 2009; Kostrakiewicz-Gierałt 2012).

In the study area, in total 1010 Trollius europaeus clumps were found and their number ranged from 1 to 250 per relevé (50 on average). The number of flowering shoots per clump was in the range from 5 to 14 (10 on average). Similar results were obtained in other regions of Poland: from several to 20 inflorescence shoots per clump in cen- 
tral Pomerania (Kochanowska 1995), from 0 to 15 generative shoots in the Olsztyn Lakeland (Juśkiewicz-Swaczyna et al. 2008), and on average 7 flowering shoots in the north-western Poland, as reported by Antkowiak (1999). In turn, Kochanowska and Gamrat (2007) highlighted the contribution of mowing to development of a great number of flowering shoots (from 20 to 40).

The height of Trollius europaeus in the analysed phytocoenoses ranged from 55 to $112 \mathrm{~cm},(86.5$ on average). The height of flowering shoots was estimated at $78-110 \mathrm{~cm}$ by Kochanowska (1995), 43-75 cm by Antkowiak (2002), and 22-60 cm by Juśkiewicz-Swaczyna et al. (2008). The greatest height of generative shoots $(100-112 \mathrm{~cm})$ was noted in the Chociel valley by Kochanowska \& Gamrat (2007), who associated the results of the biometric measurements with meadow mowing practices.

Over the last years, semi-natural Molinion caeruleae meadows have been disappearing at an increasing rate, and phytocoenoses have been undergoing species impoverishment (Zalewska 1997; Kochanowska 2005; Havlová 2006; Załuski 2007; Řezníčková 2007; Michalska-Hejduk 2001; Michalska-Hejduk \& Kopeć 2012; Kącki 2007, 2012; Trąba \& Wolański 2012; Sienkiewicz-Paderewska et al. 2012; Kulik 2014). Trollius europaeus populations present in meadow communities are threatened with extinction. Abandonment of extensive land use, triggering progressive secondary succession, is the major threat to the species. Consequently, the structure and function of the community are disturbed, characteristic rare species disappear, and the area of these communities gradually decreases (Ćwikliński \& Jasnowski 1997; Tomaszewska 2003; Kochanowska 2005; Kochanowska \& Gamrat 2007; Bochnak 2011; Michalska-Hejduk \& Kopeć 2012; Lemke et al. 2015).

With time, unmanaged Molinion caeruleae meadows are transformed into scrub communities from the alliance Filipendulion, which was observed by Kochanowska (1995) in central Pomerania, Sienkiewicz-Paderewska et al. (2012) in the Biebrza valley, and Kulik (2014) in the Łęczna-Włodawa Lakeland. The long-term investigations conducted by Falińska (1989) confirmed that Filipendula ulmaria is the first to encroach unmown sites. In unmanaged Molinion caeruleae meadows, a decline in the number of species characteristic for the alliance Molinion caeruleae and, on the other hand, an increase in the number of species representing other accompanying communities can be observed (Kącki \& Michalska-Hejduk 2010). Such processes can also be observed in the study area, where Filipendula ulmaria was one of the dominant species. Bochnak (2011) and Kochanowska \& Gamrat (2007) noted that the development of shrubs and trees largely inhibited the seed germination and the growth of juvenile Trollius europaeus specimens, which was confirmed by the study of Lemke et al. (2015).
A severe threat is also posed by mown biomass remaining on the soil surface, which greatly limits species diversity and simultaneously promotes expansion of other species (Kotańska 1993; Kochanowska 2005), induces changes in soil chemical properties, and inhibits germination of Trollius europaeus seeds (Lemke et al. 2015). Digging out and transplanting Trollius europaeus to home gardens, which was noted in the study area, is another danger (Tomaszewska 2003).

Intensive mowing and fertilisation are not recommended for conservation of Molinion caeruleae meadows, as they cause impoverishment of the species composition of the phytocoenoses and transformation toward communities with dominance of grasses, e.g. Deschampsia caespitosa (Kotańska 1993; Kącki \& Załuski 2004; Suder 2007; Kulik 2014). A common threat is the complete change in the land use category. Ecosystems undergo complete destruction and meadows are converted into arable land (Załuski 2007). Such activities were noted in the study area as well, where some of the meadow stands had been ploughed and converted into crop fields.

Under rational meadow management, i.e. mowing and removal of biomass, Trollius europaeus has a chance to compete successfully with scrubs, e.g. Filipendula ulmaria and Anthriscus sylvestris, or tree and shrub seedlings (Kochanowska 2005; Kochanowska \& Gamrat 2007; Lemke et al. 2015).

Molinion caeruleae meadows are subjected to irreversible changes caused by human activity. Abandonment of land use immediately triggers the process of natural succession towards scrub and forest communities. Therefore, active protection measures, which include management practices aimed at conservation of these phytocoenoses, should be employed.

The results of the current study indicate a number of threats for the Trollius europaeus population, the most significant of which is the progressing secondary succession. Conservation of this vulnerable species will be possible upon application of active protection practices, i.e. annual or biennial late mowing and removal of mown biomass. Additionally, permanent monitoring that will reveal changes in the phytocoenoses is recommended.

\section{References}

Antkowiak W., 1999, Struktura ekologiczna populacji pełnika europejskiego (Trollius europaeus L. subsp. europaeus) w Polsce północno-zachodniej [Ecological structure of Trollius europaeus L. subsp. europaeus populations in north-western Poland], Roczniki Akademii Rolniczej w Poznaniu - CCCXVI, Bot. 2: 3-17. 
Antkowiak W., 2002, Międzypopulacyjna zmienność populacji pełnika europejskiego (Trollius europaeus L. subsp. europaeus) w Polsce północno-zachodniej [Interpopulation variability of globe flower (Trollius europaeus L. subsp. europaeus) in north-western Poland], Roczniki Akademii Rolniczej w Poznaniu CCCXLVII, Bot. 5: 3-14.

Babczyńska-Sendek B., 2009, Significance of protection of the meadow and grassland communities for maintence the floristic diversity in the area of the south-eastern Silesian Upland (Poland), Biodiversity Research and Conservation 13: 49-60.

Bernacki L., Nowak T., Urbisz A., Urbisz A. \& Tokarska-Guzik B., 2000, Rośliny chronione, zagrożone i rzadkie we florze województwa śląskiego [Protected, threatened and rare plants in the flora of Silesia Province -Voivodship], Acta Biologica Sielsiana 35: 78-107.

Bochnak D., 2011, Stan populacji rzadkich gatunków roślin naczyniowych w zespole Molinietum caeruleae w okolicach Tyńca i Sidziny [Populations status of rare vascular plants in Molinietum caeruleae association in vicinity of Tyniec and Sidzina (S Poland)], Chrońmy Przyrodę Ojczystą 67(3): 210-217.

Ciosek T.M., Krechowski J. \& Piórek K., 2013, Pełnik europejski Trollius europaeus L. w zbiorowiskach leśnych i okrajkowych północnej części Niziny Południowopodlaskiej [Globe flower Trollius europaeus L. in forest and forest edge communities in the northen part of the Południowopodlaska Lowland], Leśne Prace Badawcze 74(3): 233-243.

Ćwikliński E. \& Jasnowski M., 1997, Łąki pełnikowe Polygono bistortae-Trollietum europaei na Pomorzu Zachodnim [Globe flower meadows Polygono bistortae-Trollietum europaei in western Pomerania], Ochrona Przyrody 54: 59-72.

Dembicz I., Kapler A., Kozub Ł. \& Zaniewski P., 2011, New locality of Trollius europaeus L. and Gladiolus imbricatus L. near Sochocin by Płońsk (central Poland), Opole Scientific Society, Nature Journal 44: 3646.

Dyrektywa 1992, Dyrektywa Rady 92/43/EWG z dnia 21 maja 1992 roku w sprawie ochrony siedlisk naturalnych oraz dzikiej fauny i flory [Council Directive 92/43/EEC of 21 May 1992 on the conservation of natural habitats and of wilde fauna and flora].

Falińska K., 1989, Plant population processes in the course of forest succession in abandoned Meadows. I. Variability and diversity of floristic compositions and biological mechanisms of species turnover, Acta Societatis Botanicorum Poloniae 58(3): 439-465.

Głowacki Z., Falkowski M., Krechowski J., Marciniuk J., Marciniuk P., Nowicka-Falkowska P. \& Wierzba M., 2003, Czerwona lista roślin naczyniowych Niziny
Południowopodlaskiej [The red list of vascular plants of the Południowopodlaska Lowland], Chrońmy Przyrodę Ojczystą 59(2): 5-41.

Havlová M., 2006, Syntaxonomical revision of the Molinion meadows in the Czech Republic, Preslia 78(1): 87-101.

Jackowiak B., Celka Z., Chmiel J., Latowski K. \& Żukowski W., 2007, Red list of vascular flora of Wielkopolska (Poland), Biodiversity Research and Conservation 5-8: 95-127.

Jakubowska-Gabara J. \& Kucharski L., 1999, Ginące i zagrożone gatunki flory naczyniowej zbiorowisk naturalnych i półnaturalnych w Polsce Środkowej [Endangered and threatened vascular plants in natural and seminatural communities in Central Poland], Fragmenta Floristica et Geobotanica, Series Polonica 6: 55-74.

Juśkiewicz-Swaczyna B., Endler Z. \& Szczesna S., 2008, Structure of a population of Trollius europaeus L. at a locality near Barczewo in the Olsztyn Lakeland, Polish Journal of Natural Sciences 23(3): 598-610.

Kącki Z., 2007, Comprehensive syntaxonomy of Molinion meadows in southwestern Poland, Acta Botanica Silesiaca, Monographiae 2: 1-136.

Kącki Z., 2012, Variability and long-term changes in the species composition of Molinia meadows in Poland: a case study Rusing a large data set from the Polish Vegetation Database. Acta Botanica Silesiaca, Monographiae 7: 1-144.

Kącki Z., Dajdok Z. \& Szczęśniak E., 2003, Czerwona lista roślin naczyniowych Dolnego Śląska [The red list of vascular plants of Lower Silesia], [in:] Z. Kącki (ed.), Zagrożone gatunki flory naczyniowej Dolnego Śląska [Endangered vascular plants of Lower Silesia], Instytut Biologii Roślin, Uniwersytet Wrocławski, Polskie Towarzystwo Przyjaciół Przyrody „Pro Natura”, Wrocław: 19-56.

Kącki Z. \& Michalska-Hejduk D., 2010, Assessment of biodiversity of Molinia meadows in Kampinoski National Parks based on biocenotic indicators, Polish Journal of Environmental Studies 19(2): 351-362.

Kącki Z. \& Załuski T., 2004, Zmiennowilgotne łąki trzęślicowe [Selino-Molinietum meadows], [in:] J. Herbich (ed.), Murawy, łąki, ziołorośla, wrzosowiska, zarośla. Poradniki ochrony siedlisk i gatunków Natura 2000 podręcznik metodyczny. Tom 3. [Grasslands, meadows, tall herb communities, heathlands, shrublands. Guide of habitats and species protection of Natura 2000 sites methodical handbook], Ministerstwo Środowiska [the Ministry of Environment], Warszawa: 159-176.

Kochanowska R., 1995, Łąki pełnikowe w dolinie Chocieli [Trollius europaeus meadows in the Chociel River valley], Chrońmy Przyrodę Ojczystą 3: 37-43. 
Kochanowska R., 2005, Pełnik europejski, róża polskich łąk [The Globe flower, a rose of polish meadows], Oficyna In Plus, Szczecin.

Kochanowska R. \& Gamrat R., 2007, Zbiorowiska trawiaste z pełnikiem europejskim (Trollius europaeus L.) w dolinie Chocieli [Grass communities with Globe flower (Trollius europaeus L.) in the river Chociel Valley], Łąkarstwo w Polsce 10: 119-129.

Kołodziejek J., 2012, Pełnik europejski Trollius europaeus L. [European Globe flower Trollius europaeus L.], [in:] R. Olaczek (ed.), Czerwona księga roślin województwa łódzkiego [The red date book of vascular plants of Łódzkie Voivodship], Ogród botaniczny w Łodzi, Uniwersytet Łódzki, Łódź: 204-205.

Kołodziejek J. \& Michalska-Hejduk D., 2004, Charakterystyka geobotaniczna łąk trzęślicowych Molinietum caeruleae na polanach śródleśnych północnej części województwa śląskiego [Geobotanic characteristic of the purple moor-grass meadow community Molinietum caeruleae on the clearings in the northern part of the Silesia Voivodeship], Fragmenta Floristica et Geobotanica Polonica 11: 141-155.

Kondracki J., 2011, Geografia regionalna Polski [Regional geography of Poland], Wyd. Nauk. PWN, Warszawa.

Kotańska M., 1993, Response of wet meadows of the Calthion alliance to variations of weather and management practices - a thirteen-year study of permanent plots, Studia Naturae 40: 1-47.

Kostrakiewicz K., 2009, The influence of shadow created by adjacent plants on phenotypic plasticity of endangered species Trollius europaeus L. (Ranunculaceae), Polish Journl of Ecology 57(4): 625-634.

Kostrakiewicz-Gierałt K., 2012, The impast of neighbourhood and gap charakter on seedling recruitment of Trollius europaeus L. and Iris sibirica L. in Molinietum caeruleae meadows, Biodiversity Research and Conservation 28: 37-44.

Kucharczyk M. \& Wójciak J, 1995, Ginące i zagrożone gatunki roślin naczyniowych Wyżyny Lubelskiej, Roztocza, Wołynia Zachodniego i Polesia Lubelskiego [Threatened vascular plants of the Lublin Upland, Roztocze, Western Volhynia and Polesie Lubelskie (Eastern Poland)], Ochrona Przyrody 52: 33-46.

Kulik M., 2014, Changes of biodiversity and species composition of Molinia meadow depending on use metod, Polish Journal of Environmental Studies 23(3): 773782.

Lemke T., Jansen A. \& Porembski S., 2015, Multiple limitations to the persistence of Trollius europaeus in a fragmented agricultural landscape in the context of metapopulation theory, Plant Ecology 216: 319-330.

Łuczaj Ł., 2011. Łąki w Komborni (PLH 180042) [Meadow in Kombornia PLH 180042], [in:] M. Rogała, A. Marcela (eds), Obszary Natura 2000 na Podkarpaciu
[Natura 2000 site in Podkarpacie], Regionalna Dyrekcja Ochrony Środowiska, Rzeszów: 146-147.

Łuczaj Ł. \& Oklejewicz K., 2001, Supplement to the flora Jasło-Sanok Basin, Fragmenta Floristica et Geobotanica Polonica 8: 276-278.

Matuszkiewicz W., 2008, Przewodnik do oznaczania zbiorowisk roślinnych Polski [Guide to identification of plant communities of Poland], Wyd. Nauk. PWN, Warszawa.

Michalska-Hejduk D., 2001, Stan obecny i kierunki zmian roślinności nieleśnej Kampinoskiego Parku Narodowego [Current state and directions of change of non-forest vegetation of the Kampinos National Park], Monographiae Botanicae 89: 1-134.

Michalska-Hejduk D. \& Kopeć D., 2012, Dynamics of semi-natural vegetation with a focus of Molinion meadows after 50 years of stricte protection, Polish Journal of Environmental Studies 21(6): 1731-1741.

Mirek Z., Piękoś-Mirkowa H., Zając A. \& Zając M., 2002, Flowering plants and pteridophytes of Poland a checklist [Krytyczna lista roślin naczyniowych Polski], W. Szafer Institute of Botany, Polish Academy of Sciences, Kraków.

Muncaciu S., Gafta D., Cristea V., Rosca-Casian A. \& Goia I., 2010, Eco-coenotic conditions and structure of Trollius europaeus L. populations in an extrazonal habitat complex (Transylvanian Carpathian Foothills). Flora - Morphology, Distribution, Functional Ecology of Plants 205(11): 711-720.

Nowak A., Nowak S. \& Spałek K., 2008, Red list of vascular plants of Opole Province, Opole Scientific Society Nature Journal 41: 141-158.

Ochyra R., Żarnowiec J. \& Bednarek-Ochyra H., 2003, Census catalogue of Polish Moses, W. Szafer Institute of Botany, Polish Academy of Sciences, Kraków.

Oklejewicz K., 1993, Flora Dołów Jasielsko-Sanockich [The flora of the Jasło-Sanok Basin], Zeszyty Naukowe UJ, Prace Botaniczne 26: 1-168.

Oklejewicz K., 1996, Charakterystyka geobotaniczna Dołów Jasielsko-Sanockich [Geobotanical description of the Jasło-Sanok Basin], Zeszyty Naukowe UJ, Prace Botaniczne 27: 1-93.

Parusel J. \& Urbisz A., 2012, Czerwona lista roślin naczyniowych województwa śląskiego [The red list of vascular plants of Silesian Voivodship], Raporty Opinie 6, Strategia ochrony przyrody województwa śląskiego do roku 2030. Raport o stanie przyrody województwa śląskiego. Czerwone listy wybranych grup grzybów i roślin województwa śląskiego [Reports opinions 6, Conservation strategy of nature of the Silesian Voivodship. The red list of chosen groups of mushrooms and plants of Silesiana Voivodship], Centrum Dziedzictwa Przyrody Górnego Śląska [Upper Silesian Nature Heritage Center], Katowice: 105-177. 
Piękoś-Mirkowa H. \& Mirek Z., 2003, Atlas roślin chronionych. Flora Polska [Atlas of protected plants. Flora of Poland], Multico Oficyna Wydawnicza, Warszawa.

Řezníčková M., 2007, Variability of the Molinion meadows in Slovakia, Biologia, Bratislava, Section Botany 62(6): 675-683.

Rozporządzenie Ministra Środowiska z dnia 9.10.2014 r. o ochronie gatunkowej roślin (Dz.U. RP 2014, poz. 1409) [Regulation of the Minister of the Environment of 9 October 2014 on the species-specific protection of plants (Dz. U. RP [Journal of Laws RP] 2014, item 1409)], 2014, Kanc. Prezesa Rady Min., Warszawa.

Sienkiewicz-Paderewska D., Borawka-Jarmułowicz B., Mastalerczuk G., Chodkiewicz A. \& Stypiński P., 2012, Wpływ zaprzestania koszenia na roślinność łąki trzęślicowej (Molinietum caeruleae) [Effects of mowing cessation on Molinietum caeruleae meadow vegetation], Woda-Środowisko-Obszary Wiejskie 12, 1(37): 167-179.

Suder A, 2007, Szata roślinna łąk wilgotnych (rząd Molinietalia caeruleae W. Koch 1996) we wschodniej części Wyżyny Śląskiej [Vegetation of wet meadows (order Molinietalia caeruleae W. Koch 1996) in the eastern part of Silesia Upland], Łąkarstwo w Polsce 10: $159-172$.

Tomaszewska K., 2003, Zmiany w składzie gatunkowym fitocenoz na porzuconych łąkach pobagiennych [Changes in species composition of plant community on the abondoned drainaged meadows], Annales Silesiae 32: 103-116.

Trąba C., 1997, Florystyczne zróżnicowanie zbiorowisk roślinności łąkowej rzędu Molinietalia w dorzeczu Łabuńki [Floristic differentiation of meadow plant communities from the order of Molinietalia in the Łabuńka River Basin], Annales UMCS, Sectio E, LII(23): 189199.

Trąba C. \& Wolański P., 2012, Zróżnicowanie florystyczne zbiorowisk łąkowych ze związków Molinion, Cnidion dubii i Filipendulion w Polsce - zagrożenia i ochrona [Floristic diversity of meadows communities representing Molinion, Cnidion dubii and Filipendulion alliance in Poland - threats and protection], Inżynieria Ekologiczna 29: 224-235.
Zając A. \& Zając M., eds, 2001, Atlas rozmieszczenia roślin naczyniowych w Polsce [Distribution Atlas of Vascular Plants in Poland], Nakładem Pracowni Chorologii Komputerowej Instytutu Botaniki Uniwersytetu Jagiellońskiego [Edited by Laboratory of Computer Chorology, Institute of Botany, Jagiellonian University], Kraków.

Zając M. \& Zając A., 2009, The geographical element of native flora of Poland [Elementy geograficzne rodzimej flory Polski], Nakładem Pracowni Chorologii Komputerowej Instytutu Botaniki Uniwersytetu Jagiellońskiego [Edited by Laboratory of Computer Chorology, Institute of Botany, Jagiellonian University], Kraków.

Zalewska J., 1997, Łąki trzęślicowe w dolinie Przemszy [The moor grass meadows in the Przemsza River Valley], Ochrona Przyrody 54: 73-79.

Załuski T., 2007, Zagrożenia i ochrona zespołów trawiastych [Threat and protection of grass communities], [in:] L. Frey (ed.), Księga polskich traw [The Book of Polish Grasses], Instytut Botaniki im. W. Szafera, Polska Akademia Nauk, Kraków: 283-316.

Zarzycki K., Trzcińska-Tacik H., Różański W., Szeląg Z., Wołek J. \& Korzeniak U., 2002, Ecological indicator values of vascular plants of Poland [Ekologiczne liczby wskaźnikowe roślin naczyniowych Polski], W. Szafer Institute of Botany, Polish Academy of Science, Kraków.

Zelnik I., 2005, Meadows of the order Molinietalia caerulea Koch 1926 in south-eastern Slovenia, Fitosocjologia 42(1): 3-32.

Żukowski W. \& Jackowiak B., 1995, Ginące i zagrożone rośliny naczyniowe Pomorza Zachodniego i Wielkopolski [Endangered and threatened vascular plants of Western Pomerania and Wielkopolska], Bogucki Wyd. Naukowe, Poznań. 